\title{
Vulvovaginitis pada anak
}

\author{
Sudung O. Pardede
}

Vulvovaginitis merupakan masalah ginekologi yang paling sering ditemukan pada anak dan remaja, tetapi umumnya masih kurang mendapat perhatian di kalangan dokter spesialis anak. Vulvovaginitis dapat disebabkan infeksi bakteri, virus, jamur, protozoa, cacing, benda asing, trauma, reaksi alergi, atau merupakan bagian dari penyakit sistemik. Vulvovaginitis bakterialis dapat berupa vulvovaginitis non spesifik dan spesifik. Vulvovaginitis non spesifik biasanya terjadi pada pasien dengan higiene perineum yang buruk, dan vulvovaginitis bakterialis spesifik terutama disebabkan Gardnerella vaginalis. Pengeluaran sekret vagina sering merupakan gejala klinis yang membawa anak berobat ke dokter. Gejala lain vulvovaginitis adalah pruritus, sering berkemih, disuria, atau enuresis. Dalam tata laksana vulvovaginitis, perlu diperhatikan higiene perineum, tidak mengenakan pakaian yang ketat, menggunakan sabun yang lunak, dan memelihara vulva tetap bersih, sejuk, dan kering. Pengobatan vulvovaginitis tergantung pada penyebabnya. Vulvovaginitis bakterialis dapat diterapi dengan antibiotik seperti amoksisilin atau sefalosporin. Infeksi jamur diterapi dengan anti jamur imidazol, mikonazol, klotrimazol, dan nistatin. Vulvovaginitis trikomonads diterapi dengan metronidazol. Krim estrogen topikal atau salep polisporin dapat membantu.

Kata kunci: vulvovaginitis, spesifik, nonspesifik, leukorhoe

$\mho$ ulvovaginitis merupakan masalah ginekologi yang paling sering ditemukan pada anak dan remaja. ${ }^{1-6}$ Meskipun kelainan ini sering ditemukan, umumnya masih kurang mendapat perhatian di kalangan dokter spesialis anak ${ }^{1,2}$ dan jarang dibicarakan pada pertemuan ilmiah bidang kesehatan anak. Insiden vulvovaginitis pada anak sulit diketahui dengan pasti, ${ }^{3}$ meskipun menurut Altchek, hampir semua anak perempuan pernah mengalami vulvovaginitis minimal satu kali. ${ }^{4}$ Jaquiry dkk., 1999

\footnotetext{
Alamat korespondensi:

Dr. Sudung O. Pardede, Sp.A(K).

Divisi Nefrologi. Departemen Ilmu Kesehatan Anak FKUI-RSCM. Jl. Salemba no. 6, Jakarta 10430.

Telepon: 021-3915179. Fax.021-390 7743.
}

melaporkan bahwa 50\% anak normal pernah mengalami iritasi genitalia dan 30\% dengan kemerahan vagina. ${ }^{5}$ Anak dengan gejala vulvovaginitis sering dicurigai dan didiagnosis sebagai infeksi saluran kemih karena pada urinalisis sering ditemukan leukosituria, ${ }^{1,2}$ sehingga pemeriksaan vulva pada anak hendaknya rutin dilakukan. ${ }^{4}$

Vagina merupakan media yang baik bagi kuman dan anak sangat rentan terhadap vulvovaginitis. Jaringan vulva yang lunak mudah mengalami iritasi dan posisi anatomi vulva yang berdekatan dengan anus merupakan faktor yang mempermudah perpindahan kuman dari anus ke daerah vulvovaginal. Vulva pada anak tidak mempunyai alat protektif seperti labia yang tebal dan rambut pubis seperti pada dewasa. Labia mayora akan terbuka jika anak jongkok sehingga jaringan di dalam cincin himen yang sensitif akan 
mudah terpapar. ${ }^{1,2}$ Selain itu, higiene perineum yang buruk, kebiasaan cebok dari belakang ke depan, penggunaan alat toilet duduk, kebiasaan bermain di tanah, dan menggaruk daerah vulva dengan jari kotor merupakan faktor yang mempermudah terjadinya infeksi vulva. ${ }^{4}$ Masturbasi juga turut berperan dalam terjadinya vulvovaginitis meskipun sangat jarang. ${ }^{1,2}$

Manifestasi klinis vulvovaginitis sangat bervariasi, dapat berupa disuria, rasa ingin berkemih (frequency), vaginal discharge, eritema, dan pruritus. Iritasi vulvovaginal pada anak lebih mudah terjadi karena tidak adanya bantalan lemak labia dan rambut pubis yang melindungi genitalia eksterna. ${ }^{1,2,4}$

\section{Fisiologi vagina}

Pada neonatus, vagina biasanya steril dengan $\mathrm{pH}$ yang alkali, ${ }^{6}$ dan dapat ditemukan pengeluaran sekret vagina yang transient, fisiologis, berwarna putih susu yang terjadi karena stimulasi estrogen maternal terhadap vagina. Kadang-kadang dapat terlihat darah baik secara mikroskopis atau makroskopis yang berasal dari perdarahan endometrium karena efek estrogen. Himen dapat menonjol disertai pembesaran kelenjar mammae. ${ }^{4}$

Pada bayi usia 3-6 minggu, terdapat penurunan efek estrogen maternal, disertai dinding vagina yang menjadi tipis, halus, dilapisi oleh sel epitel kuboid, dan mudah mengalami laserasi oleh trauma. Selain itu mukosa vagina belum mengandung glikogen dan Lactobacillus doderlein, $\mathrm{pH}$ yang netral, dan mengandung lebih sedikit antibodi dibandingkan dengan remaja dan dewasa. Vulva, labia, kelenjar endoservikal, dan fundus uterus belum berkembang, dan klitoris tampak normal atau sedikit membesar. ${ }^{4,6}$

Pada masa perkembangan remaja, terjadi pertumbuhan rambut pubis, penebalan lapisan lemak pada labia sehingga labia membesar. Kelenjar endoservikal juga akan membesar. Peningkatan estrogen pada masa pubertas akan menimbulkan perubahan fisiologis pada mukosa vagina termasuk $\mathrm{pH}$ dan flora bakteri serta perubahan epitel vagina menjadi sel epitel skuamosa, dan menyebabkan penebalan vagina sehingga membuat vagina mempunyai rugae, lebih panjang, lebih lebar dengan adanya forniks, serta meningkatkan proliferasi sel superfisial yang kaya glikogen. ${ }^{6,7}$ Laktobasilus dan flora bakteri normal vagina akan menggunakan glikogen sebagai substrat dan meningkatkan produksi asam laktat dan asam asetat yang menyebabkan lingkungan asam dengan $\mathrm{pH}$ 3,5-5,0. Dengan demikian, bakteri komensal terutama laktobasilus sangat penting sebagai mekanisme pertahanan normal dalam vagina. ${ }^{7}$

Epitel skuamosa mukosa vagina sangat sensitif terhadap hormon steroid. Pada kadar estrogen yang rendah, epitel menjadi atrofi dan tipis sehingga mudah diinvasi kuman. Vulvovaginitis berulang biasanya akan berhenti apabila anak memasuki usia remaja dan $\mathrm{pH}$ vagina menjadi lebih asam. ${ }^{1,2}$

\section{Flora normal vagina}

Berbagai flora normal dapat ditemukan dalam vagina antara lain: Lactobacillus doderlein, Bacteroides fragilis, Enterobacteriaceae, Neisseria sikka, Streptokokus sp., Stafilokokus sp, difteroid, mikoplasama, Gardnerella vaginalis, Ureaplasma urealitikum, Candida albicans, dan beberapa kuman aerob dan anaerob. ${ }^{7}$

\section{Penyebab vulvovaginitis}

Penyebab vulvovaginitis pada anak antara lain ${ }^{4}$

1. Infeksi bakteri

- non spesifik, campuran beberapa bakteri

- spesifik: -non gonorhoe yang dapat berasal dari farings, kulit telinga, saluran kemih, dan usus, (Streptococcus hemolyticus grup A, meningokokus, shigela); Gardnerella vaginalis

- gonorhoe

2. Infeksi oleh mikroorganisme lain

- kandida, trikomonas, amuba dan kistosomasis

3. Infestasi cacing: enterobiasis (pinworm)

4. Faktor fisik lokal

- benda asing

- trauma: fisik, kimiawi, suhu

- kelainan ginekologi: neoplasma, polip, perlengketan labia

- kelainan urologi: prolaps uretra, ureter ektopik, enuresis

- kelainan rektal: fistula kongenital, fisura perineum, pruritus

- pembalut: ruam popok, leotards, ballet bottom dancers

- reaksi kontak: iritan, alergi 
5. Penyakit sistemik dengan manifestasi ke vulva

- campak, demam skarlet, cacar air, difteria

- tipus abdominalis, disentri

- kelainan darah atau blood dyscrasia

- abses pelvis, penyakit inflamasi pelvis

6. Penyakit kulit vulva

- dermatitis seborhoika, psoriasis, dermatitis atopi, ptiriasis, liken sklerosus

- kondiloma akuminata, herpes simpleks, moluskum kontagiosum

- infeksi bakteri

- tinea, kandida, intertrigo

- pedikulosis, skabies

7. Sifilis dan penyakit kelamin

8. Psikosomatis

Jaquiery dkk. 1999 melaporkan bahwa sebagian besar $(80 \%)$ penyebab vulvovaginitis adalah non infeksi, seperti higiene yang buruk, trauma, iritasi zat kimia, obat-obatan (antibiotik topikal, krim kortikosteroid dan hormon, kemoterapi), dermatitis kontak, kelainan kulit, dan benda asing. ${ }^{5}$

\section{Manifestasi klinis}

Manifestasi klinis vulvovaginitis sangat bervariasi dan tergantung pada penyebabnya. Pada anak besar dapat ditemukan rasa nyeri, gatal, rasa terbakar di sekitar vulva, yang timbul secara intermiten atau terus menerus, serta disuria jika urin mengenai daerah vulva (disuria vulva). Keluhan ini sering kurang diperhatikan sehingga tanda klinis yang menonjol adalah efek sekunder akibat garukan, infeksi sekunder, edema, maserasi, ekskoriasi, dan efek pengobatan. 4,8

Leukorhoe merupakan manifestasi klinis vulvovaginitis yang sering ditemukan, tetapi perlu diingat bahwa leukorhoe dapat fisiologis. Leukorhoe fisiologis merefleksikan kadar estrogen dalam darah, yang sering terlihat berupa bercak kekuningan pada celana atau sekret yang jernih, putih atau mukoid, tidak berbau, tidak disertai pruritus, vulva tidak meradang, dan secara mikroskopis tampak basil Doderlein. ${ }^{7}$

Pengeluaran sekret vagina yang patologis sering merupakan gejala primer vaginitis, vulvitis, atau vulvovaginitis yang membawa anak berobat ke dokter. Pruritus, sering berkemih, disuria, atau enuresis dapat merupakan gejala vulvovaginitis. Vulvitis biasanya ditandai dengan disuria dan pruritus disertai eritema vulva, dan umumnya perjalanan penyakit lebih lama daripada vaginitis. Vaginitis ditandai dengan pengeluaran sekret vagina tanpa disertai disuria, pruritus, atau eritema vulva. Vulvovaginitis merupakan gabungan gejala keduanya. Meskipun ada berbagai penyebab vulvovaginitis pada anak, tetapi penyebab yang paling sering adalah higiene perineum yang buruk, infeksi kandida, dan benda asing. ${ }^{1,2,8}$ Perlu diketahui bahwa infeksi pada vagina, serviks, uterus, tuba Fallopi, dan saluran kemih dapat menimbulkan gejala yang hampir sama seperti disuria, pruritus vulva, dan meningkatnya cairan yang dikeluarkan vagina. ${ }^{4}$

Pierce dan Hart (1992) melaporkan manifestasi klinis vulvovaginitis yang sering ditemukan yaitu kemerahan genitalia $(84 \%)$, rasa nyeri $(54 \%)$, pengeluaran sekret (discharge) (52\%), disuria dengan atau tanpa frequency (51\%), gatal-gatal (40\%), adanya sekret $(33 \%)$, nyeri abdomen $(26 \%)$, perdarahan vaginal $(19 \%)$, perianal yang kotor $(18 \%)$, dan lesi kulit spesifik (14\%). ${ }^{9}$

Disuria merupakan gejala vulvovaginitis yang sering ditemukan. Demetriou dkk. (1982) melaporkan bahwa $41 \%$ disuria disebabkan vaginitis, $25 \%$ disebabkan kelainan lokal, dan 17\% disebabkan infeksi saluran kemih. ${ }^{10}$ Jika memungkinkan perlu dibedakan vulvitis primer disertai vaginitis sekunder dari vaginitis primer dengan vulvitis sekunder. Vulvitis primer lebih sering ditemukan, biasanya etiologinya tidak spesifik, dan berkaitan dengan higiene yang buruk. Pada biakan vagina ditemukan campuran beberapa kuman. Vaginitis primer lebih jarang dan biasanya etiologinya spesifik. $^{4}$

\section{Diagnosis}

Diagnosis vulvovagintis ditegakkan berdasarkan anamnesis, pemeriksaan fisik, dan pemeriksaan penunjang. Anamnesis dapat diperoleh dari orangtua, babysitter, saudara kandung, atau pasien sendiri. Perlu ditanyakan kapan gejala timbul, apakah ada gejala kelainan saluran nafas, saluran kemih, infeksi kulit, enuresis, diare, nyeri abdomen, trauma, pakaian yang dikenakan, bau, dan lain-lain. Selain itu, perlu ditanya apakah terdapat gatal, rasa terbakar, leukorhoe, perdarahan, bau tidak enak, disuria, dan nyeri pada waktu defekasi, serta bagaimana pengobatan sebelumnya dan hasilnya. ${ }^{4}$ 
Pada pemeriksaan pasien perlu dilihat pakaian, celana dalam, dan popok. Pada pemeriksaan vulva, dicari tanda garukan, cairan vagina, warna dan bau cairan. Pada vulva tampak tanda radang dan edema. Dengan jari telunjuk dan jempol, labia dibuka untuk melihat himen. Kadang-kadang diperlukan colok dubur untuk memeriksa benda asing dalam vagina, serviks, atau tumor pelvis. Kemungkinan adanya cacing enterobius (kermi) diperiksa dengan usapan perianal. ${ }^{4,8}$

Pemeriksaan leukosit esterase dengan dipstik merupakan pemeriksaan skrining yang cepat dalam menegakkan diagnosis vaginitis dan servisitis. Pemeriksaan ini dapat mengidentifikasi trikomonas, kandida, dan vaginosis bakterial, serta infeksi oleh gonokokus dan klamidia. ${ }^{1,2}$ Biakan sekret vagina, sitologi, dan vaginoskopi perlu dilakukan untuk evaluasi vulvovaginitis, namun pada kebanyakan kasus vulvitis primer nonspesifik tidak diperlukan vaginoskopi. Vaginoskopi biasanya diperlukan pada vulvovaginitis persisten atau berulang, perdarahan vagina, kecurigaan terhadap benda asing, neoplasma, atau anomali kongenital. ${ }^{4,8}$

\section{Vulvovaginitis bakterialis}

\section{a. Vulvovaginitis non spesifik}

Sebagian besar (70\%) vulvovaginitis pada anak merupakan vulvovaginitis primer non spesifik dan biasanya terjadi pada pasien dengan higiene perineum yang buruk. Sekitar 68\% vulvovaginitis pada anak disebabkan oleh bakteri koliform yang berasal dari feses. Bakteri lain yang juga sering sebagai penyebab vulvovaginitis non spesifik adalah streptokokus dan stafilokokus koagulase positif.

Pakaian yang ketat seperti jeans, popok dari bahan karet atau plastik, bahan kimia, kosmetik, sabun atau deterjen yang digunakan untuk mandi atau laundri dapat menimbulkan iritasi dan vulvovaginitis non spesifik. ${ }^{1,2}$ Pada pemeriksaan vulva didapatkan eritema hingga edema, ekskoriasi, dan infeksi sekunder. Dapat ditemukan sisa tinja di sekitar anus, smegma di sekitar klitoris dan labia minora. Sekret yang keluar biasanya berwarna coklat atau kehijauan dan berbau busuk, dengan $\mathrm{pH}$ vagina antara 4,7 - 6. ${ }^{4}$ Adanya iritasi dan kehilangan jaringan atau denudasi vulvovaginal akan mempermudah absorbsi obat topikal sehingga mempermudah terjadinya dermatitis kontak terhadap analgesik atau antihistamin topikal, maupun obat lain seperti neomisin, paraben, dan thimerosol. ${ }^{4}$

Pada biakan kuman vagina biasanya terdapat gabungan antara difteroids, stafilokokus, streptokokus, dan organisme koliform. Ada juga kuman yang biasanya terdapat dalam keadaan normal tetapi potensial menjadi patogen seperti Gardnerella influenzae dan bakteri anaerob. ${ }^{4}$ Vulvovaginitis non spesifik dapat menyebabkan infeksi kronis yang mengakibatkan gangguan psikologis pada anak maupun orangtua. ${ }^{1,2}$

\section{b. Vulvovaginitis spesifik}

Vulvovaginitis bakterial spesifik pada anak terutama disebabkan oleh Gardnerella vaginalis (Corinebacterium vaginalis, Hemophyllus vaginalis). Organisme lain yang dapat menyebabkan vulvovaginitis spesifik adalah enterokokus, Shigela fleksneri, Shigela sonnei, dan bakteri anaerob seperti peptokokus, peptostreptokokus, Veillonella parvula, eubakterium, propionibakterium, dan spesies bakteroides. Selain bakteri, vulvovaginitis dapat juga disebabkan oleh kandida, protozoa, helmintes, dan virus. ${ }^{1,2}$ Kuman dari urin dapat memasuki vagina melalu urin yang merembes dan menyebabkan vaginitis. Diagnosis vaginitis bakteral spesifik non gonorhoe memerlukan biakan, tetapi sulit menyingkirkan kemungkinan kontaminasi meskipun dengan vaginoskopi. ${ }^{4}$

Gonorhoe merupakan penyakit seksual yang paling sering pada anak dan biasanya menyebabkan vaginitis sedangkan pada dewasa menyebabkan endoservisitis. Gonorhoe pada anak biasanya berasal dari ibu atau sexual abuse. Farings, rektum, dan vagina bayi dapat terinfeksi jika kontak dengan sekret vagina yang terinfeksi sewaktu melalui jalan lahir. Gonorhoe dapat asimtomatik meskipun biasanya terdapat sekret vagina yang putih, kuning, atau kehijauan, berbau, dan disuria. Pada genitalia tampak eritema labia, dan iritasi uretra. Pada keadaan kronik, sekret vagina biasanya sedikit dan cair. Gonorhoe ditegakkan jika didapatkan diplokokus gram negatif oksidase positif, dan perlu dilakukan biakan dan mencari sumber infeksi. ${ }^{4,6}$

Gardnerella vaginalis jarang menyebabkan vaginitis pada anak. Pada neonatus infeksi biasanya berasal dari jalan lahir dan jarang berkembang menjadi sistemik. Kuman ini lebih menyukai vagina estrogenik. Masa inkubasi 5-10 hari. Jumlah sekret vagina bervariasi, 
dengan $\mathrm{pH}$ 5-6. Biasanya ditandai dengan rasa gatal, seperti terbakar, dan inflamasi vagina. ${ }^{4}$

\section{Vulvovaginitis oleh mikroba lain}

Kandida albikans dalam vagina dapat bersifat saprofit atau patogen menyebabkan vulvovaginitis. Diperkirakan sekitar 80-95 \% vulvovaginitis disebabkan oleh Candida albicans. Jamur lain yang menyebabkan vulvovaginitis antara lain Torulopsis glabrata, kriptokokus, dan sakaromises. ${ }^{6,7}$ Vulvovaginitis kandidiasis biasanya dicurigai jika terdapat kandidiasis mukokutaneous kronik. ${ }^{1,2,8}$ Beberapa faktor predisposisi terjadinya vulvovaginitis kandidiasis adalah pemakaian antibiotik terutama sefalosporin dan ampisilin, diabetes melitus, obesitas, pemberian kortikosteroid dan imunsupresan, penyakit imunodfisensi, keganasan, kelainan darah (anemia aplastik, leukemia, agranulositosis), endokrinopati (hipotiroidisme, hipertiroidisme, penyakit Addison, hipoparatiroidisme), anemia defisiensi besi, glukosuria renal, pankreatitis, hipersensitivitas dan reaksi alergi, pakaian ketat dari nilon, penggunaan alat toilet terinfeksi, trauma vagina dan vulva, malabsorbsi, higiene perineum yang buruk, dan lain-lain. Infeksi kandida sering dikaitkan dengan ruam popok. Vulvovagintis kandidiasis sering ditandai dengan pruritus, rasa terbakar, vulva dan vagina yang eritematous, ekskoriasi atau fisura perianal, dermatitis papulopustular perianal, dan sekret vagina yang putih kental yang kadang-kadang berbentuk plak yang menempel pada dinding vagina. ${ }^{6,7}$

Trikomonas vaginalis adalah protozoa flagelata anaerob dan satu-satunya spesies trikomonas yang patogenik pada urogenital dan menyebabkan trikomoniasis Trikomonas lebih menyukai vagina yang estrogenik. Diperkirakan 2,5-5\% neonatus yang ibunya terinfeksi trikomonas akan tertular trikomonas. Penyakit ini dapat tertular melalui pemakaian handuk yang mengandung organisme ini. Pada dewasa, penyakit ini sering ditularkan melalui kontak seksual. Manifestasi klinis dapat asimtomatik atau berupa pengeluaran sekret vagina yang berbau dengan $\mathrm{pH} 5-$ 7, dapat ditemukan tanda vaginitis, vulvitis, uretritis, dan disuria dengan piuria tanpa bakteriuria. Diagnosis perlu dikonfirmasi dengan menemukan trikomonas pada pemeriksaan mikroskop. Meskipun trikomoniasis sangat jarang, perlu dipikirkan pada vaginitis rekuren atau resisten. ${ }^{4,6,7}$

\section{Vulvovaginitis oleh cacing}

Vulvovaginitis berulang dapat disebabkan cacing Enterobius vermikularis (pinworms), dan terjadi pada $20 \%$ pasien yang terinfeksi cacing ini. Cacing betina akan meletakkan telurnya di sekitar anus. Pasien biasanya mengeluh gatal-gatal sehingga menggaruk daerah yang gatal pada malam hari. ${ }^{1,2,8}$

\section{Vulvovaginitis oleh faktor fisik}

Benda asing pada vulva dapat menyebabkan vulvovaginitis yang biasanya ditandai dengan perdarahan vagina, sering ditemukan pada umur 3-8 tahun. Sekitar $1-4 \%$ perdarahan vagina pada anak dan $18 \%$ pada umur prapubertas disebabkan benda asing. ${ }^{1,2,4}$ Adanya benda asing dicurigai jika terdapat sekret vagina berdarah disertai bau tidak enak; perdarahan dapat persisten dengan jumlah yang banyak. Pemeriksaan radiologi dan ultrasonografi dapat membantu mencari benda asing. 1,2 Benda ini tidak dapat dideteksi dengan colok dubur dan foto X-ray, dan tidak sembuh dengan obat. ${ }^{4}$

Trauma pada anak sering terjadi karena terjatuh atau luka saat bermain, dan terlihat dengan adanya ekimosis pada vulva atau perineum. Meskipun tidak ada luka luar, dapat ditemukan perdarahan vagina karena laserasi, atau perdarahan karena luka transvaginal hingga kandung kemih, rektum, atau rongga peritoneum. Jika terdapat tanda trauma, perlu dipikirkan kemungkinan kejahatan seksual. Laserasi vulva kecil dapat ditatalaksana dengan kompres dingin untuk menghentikan perdarahan. Perdarahan yang persisten atau banyak harus diperiksa lebih lanjut untuk menghentikan perdarahan. 4,8

Kelainan saluran kemih seperti enuresis, prolaps uretra, dan ureter ektopik akan menyebabkan pengeluaran urin persisten yang dapat menimbulkan vulvitis. Kelainan kongenital seperti fistula antara rektum dan vagina atau vesika urinarius dapat juga menyebabkan infeksi vulva. ${ }^{4}$ Ruam popok biasanya terjadi pada umur sekitar 3 bulan. Dalam popok, bakteri dari tinja akan bereaksi dengan urin membentuk amonia dan iritan lain. Pada vulva tampak eritema, erosi, vesikulasi, dan infeksi. Kandidiasis sekunder sering juga terjadi yang tampak berupa papula dan pustula. ${ }^{4}$ 


\section{Penyakit sistemik bermanifestasi ke vulva}

Beberapa penyakit sistemik dapat bermanifestasi di vulva menyebabkan vulvovaginitis, antara lain campak, scarlet fever, cacar air, difteria, tifus abdominalis, sindrom disentri, kelainan darah, penyakit inflamatori pelvis, dan granulomatous bowel diseases. ${ }^{4}$

\section{Penyakit kulit vulva}

Lesi Molluscum contagiosum yang disebabkan virus Molluscum contagiosum atau poxvirus tampak berupa kelainan papul yang umbilicated. Lesi pada vulva terjadi melalui autoinokulasi atau kontak dengan pasien yang terinfeksi. Masa inkubasi $2-7$ minggu. Diagnosis ditegakkan berdasarkan pemeriksaan mikroskop dengan menemukan badan inklusi virus yaitu badan moluskum di dalam pusat inti. Terapi adalah menghilangkan lesi biasanya dengan kuret, kriosurgeri, atau elektrokauter. ${ }^{1,2}$

Virus Herpes simpleks yang menyerang vulva adalah tipe 1 dan 2. Meskipun tidak spesifik, tipe 1 lebih sering menyerang daerah genital dan tipe 2 lebih sering mengenai fasial-oral. Lesi biasanya berupa papul yang berubah menjadi vesikel. Diagnosis defenitif ditegakkan dengan biakan virus atau menemukan virus dengan mikroskop elektron. Pemberian asiklovir topikal akan menurunkan shedding virus dan mempercepat penyembuhan. ${ }^{1,2}$

Impetigo biasanya disebabkan Staphyllcoccus aureus grup II tipe 71, yang dapat berasal dari ibu atau orang lain yang kontak dengan pasien. Impetigo sering mengenai vulva dan periumbilikal dengan lesi yang menjadi krusta. Pengobatan dengan antibiotik dan jika terapi tidak adekuat dapat terjadi penyebaran infeksi. ${ }^{1,2}$ Intertrigo dapat terjadi pada daerah genitokruris yang sering mengalami pergesekan dan lembab, umumnya terdapat pada orang gemuk. Lesi tampak mengalami kemerahan dan maserasi. Pengobatan dilakukan dengan higiene yang baik dan kombinasi emolien dengan kortikosteroid. ${ }^{1,2}$ Folikulitis dapat terjadi spontan atau sekunder yang ditandai dengan erupsi papulopustular akibat inflamasi folikel rambut. Pustula biasanya berukuran $2-10 \mathrm{~mm}$. Infeksi ini sering disebabkan oleh Staphyllcoccus aureus meskipun dapat juga disebabkan Pseudomonas aeruginosa. Kelainan ini diterapi dengan larutan povidon iodine topikal dan antibiotik sefalosporin atau eritromisin. ${ }^{2}$
Dermatitis seborhoika memberikan gambaran berupa efloresensi eritematosus, berminyak, berbatas tegas, yang dapat ditemukan di wajah, kepala, dada, dan daerah lipatan di seluruh tubuh. Dapat menyebabkan fisura pada vulva yang disertai infeksi sekunder. Infeksi sekunder karena kuman dan jamur menyebabkan rasa nyeri, pruritus, disuria, dan perdarahan vagina. Fase akut memberikan respons yang baik dengan larutan Burrow (larutan aluminium asetat). Faktor yang dapat menyebabkan eksaserbasi harus dihindari seperti pakaian yang ketat atau yang terbuat dari karet. Antibiotik atau anti jamur sistemik diberikan jika ada infeksi sekunder. ${ }^{1,2}$ Dermatitis kontak ditandai oleh lesi yang sesuai dengan bentuk iritan. Vulva akan tampak eritematous, edema, kadangkadang disertai vesikel atau pustula. Dermatitis kontak kronik tampak berupa likenifikasi atau penebalan kulit, dapat disertai infeksi sekunder oleh bakteri atau jamur. Beberapa penyebab yang sering ditemukan antara lain sabun, bedak, obat topikal, busa sabun mandi, kertas toilet, rubber, pakaian. Tata laksana adalah dengan menghindari iritan, kompres dengan larutan Burrow selama fase akut. Dapat diberikan kortikosteroid lunak secara topikal seperti hidrokortison 0,5-1\%. 1,2 Dermatitis atopi ditemukan pada 3\% anak dan biasanya pasien menderita riwayat atopi. Lesi valvular ditandai dengan pruritus, eritema, papula, vesikel, dan krusta. Pruritus akan menyebabkan pasien menggaruk yang menyebabkan ekskoriasi, dapat disertai infeksi sekunder oleh bakteri atau jamur. Antihistamin diberikan untuk menghilangkan pruritus. Dapat juga diberikan sabun lunak dan lubrikan, kortikosteroid topikal, dan infeksi diobati dengan antibiotik dan antijamur. ${ }^{1,2}$ Psoriasis vulva tampak berupa lesi papul violaseus atau plak yang tebal, lengket, berwarna keperakan, biasanya berupa scaly patches dan umumnya terdapat pada mons pubis. Lesi vulva diterapi dengan krim kortikosteroid dan antibiotik, serta menanggulangi pruritus. ${ }^{2}$ Liken sklerosus adalah kelainan atropik kronik berupa papul kecil berdiameter beberapa milimeter, berwarna merah jambu, dengan puncak yang rata, dapat disertai vesikel dan bula yang menyebar ke atas vulva dan disertai perdarahan. Lesi pada anogenital sering terlihat seperti angka delapan atau jam gelas. Onset pada anak biasanya terjadi sebelum umur 7 tahun dan pernah dilaporkan pada bayi umur beberapa minggu. Penyebab penyakit ini belum diketahui tetapi diyakini merupakan kelainan imunologis. Diagnosis pasti ditetapkan dengan biopsi. 
Pengobatan biasanya simtomatik dengan emolient dan kortikosteroid topikal. Dapat juga diberikan estrogen dan androgen topikal, tetapi obat ini dapat menyebabkan perdarahan vagina dan pembesaran klitoris. Terapi dapat juga dilakukan dengan vaporisasi laser dan terapi bedah. ${ }^{1,2}$ Liken planus vulva ditandai dengan lesi vulva berupa papula violaseus yang dapat merangsang leukoplakia. Lesi biasanya gatal dan dapat disertai ekskoriasi, maserasi, dan sering terjadi eksaserbasi atau rekurensi. Diagnosis ditegakkan dengan biopsi. Tata laksana adalah dengan pemberian kortikosteroid intralesi dan antihistamin untuk menanggulangi pruritus. Perlu pemantauan dan evaluasi histologis terhadap kemungkinan karsinoma sel skuamosa. ${ }^{1,2}$ Liken simpleks kronikus (neurodermatitis) merupakan kelainan kronik dengan lesi likenifikasi berbentuk plak yang menyebabkan pruritus, sehingga pasien menggaruk kulit di daerah vulva dan menyebabkan inflamasi, ekskoriasi, dan fisura. labia tampak hiperemis dan edema. Keadaan ini jarang ditemukan pada anak. Pengobatan adalah dengan antihistamin dan kortikosteroid topikal atau intralesi misalnya triamsinolon. ${ }^{1,2}$

Human papilomavirus dapat menyebabkan infeksi vulva. Human papilomavirus terdiri dari beberapa serotipe dan yang sering menyebabkan kelainan pada anogenital adalah tipe 6,11, 16, dan 18. Pengobatan biasanya simtomatik, tergantung pada gejala dan tanda klinis. ${ }^{2}$ Ulkus aptosa pada daerah genital biasanya berukuran 1-10 mm. Ulkus ini dapat berulang dan hilang dalam 7-10 hari. Penyebabnya belum diketahui, dan pengobatan biasanya dengan kortikosteroid topikal dan bila perlu diberikan anestesi topikal. ${ }^{2}$ Malassezia furfur disebabkan oleh Pitirosporum orbiculare dan tampak sebagai makula pada muka dan area genitalia. Diagnosis ditegakkan dengan menemukan hypha dan spora pada sediaan dengan $\mathrm{KOH} 10 \%$. Kelainan ini diterapi dengan imidazol topikal. ${ }^{1,2}$

\section{Vulvovaginitis yang berhubungan dengan penyakit lain}

Pada eritema multiformis, terdapat juga lesi pada genitalia berupa ulkus selain lesi pada telapak tangan, kaki, dan bagian tubuh lainnya. Lesi biasanya menetap kira-kira 1 minggu, dan biasanya terjadi karena alergi obat atau gejala yang mendahului herpes simpleks. ${ }^{2}$
Sindrom Stevens-Johnson merupakan bentuk eritema multiformis yang menyebabkan kelainan pada genitalia, kulit, mukosa, dan mata, yang ditandai dengan masa prodormal 1-14 hari berupa demam, nyeri kepala, nyeri tenggorokan, dan malaise. Umumnya penyakit ini disebabkan alergi obat. ${ }^{2}$ Nekrolisis epidermal toksik biasanya terjadi karena alergi obat dengan manifestasi klinis yang hampir sama dengan sindrom Steven Johnson. Kurang lebih 20$30 \%$ pasien akan meninggal jika penanganan tidak adekuat. ${ }^{2}$ Penyakit Crohn merupakan penyakit granulomatosa kronik yang mengenai saluran cerna, dan pada $24 \%$ terdapat kelainan ginekologi. Lesi di vulva tampak dalam dan multipel berupa eritema, edema, ulkus, dan infeksi sekunder. Antibiotik dan steroid merupakan terapi primer terhadap kelainan saluran cerna, sedangkan lesi vulva diterapi dengan steroid topikal dan antibiotik sistemik. ${ }^{1,2}$ Penyakit Bechet merupakan penyakit organ multisistem yang kronik akibat vaskulitis oklusif, ditandai dengan ulkus aptosa berulang di mulut dan genitalia, uveitis, vaskulitis kutaneus, sinovitis, dan meningoensefalitis. Ulkus genitalia seperti vulvovaginitis ditemukan pada $58-78 \%$. Kelainan tampak berupa lesi makular kemerahan dan nyeri. Terapi biasanya simtomatik dengan anestesi lokal lidokain. Steroid intralesi dapat digunakan pada ulkus simtomatik, dan pada kasus berat dapat diberikan kolkisin atau metotreksat. ${ }^{1,2}$

\section{Beberapa keadaan yang mempermudah terjadinya vulvovaginitis}

Kista vagina sangat jarang dan umumnya ditemukan secara kebetulan. Kista ini berasal dari duktus Wollfian atau duktus Mulleri atau kista inklusi epitelial. Terapi tergantung pada lokasi kista, biasanya diobservasi dan reseksi dilakukan jika kista menjadi simtomatik. ${ }^{2,6}$

Kista duktus Gartner merupakan bagian rudimener duktus Wolffian. Pada perempuan duktus akan mengalami regresi lengkap, namun dapat menetap di sepanjang dinding anterolateral vagina. Tindakan reseksi dilakukan tergantung pada gejala yang timbul. ${ }^{2,6}$

Klitoritis sering disebabkan oleh kuman yang sama dengan penyebab vulvovaginitis. Klitoritis dapat disertai adhesi klitoris, ${ }^{1}$ pruritus, dan tanda garukan pada genitalia anterior. ${ }^{2}$ Terapi dilakukan dengan kompres hangat dan retraksi klitoris. Jika sudah 
mengganggu, dapat diberikan krim estrogen pada malam hari selama 1-2 minggu dan sangat efektif dalam memisahkan perlengketan. ${ }^{2}$

Adhesi labia disebut juga dengan aglutinasi labia, fusi labia, fusi vulva, sinekie vagina, koalesens labia minora, oklusi vestibulum vagina, dan gynsatresia, ditandai dengan perlengketan labia minora pada garis tengah di daerah inferior klitoris, biasanya asimtomatik, dan umumnya terdapat pada anak $<6$ tahun. Perlengketan labia minora dapat menimbulkan vulvovaginitis subklinis dan biasanya tidak berbahaya. Perlengketan ini dapat disebabkan inflamasi lokal seperti infeksi, trauma lokal, iritasi, dan keadaan hipoestrogenik. Adhesi labia perlu dibedakan dengan jaringan parut labia minora, himen imperforata, hipertrofi klitoris, dan interseksualitas. Penumpukan urin dalam vagina dan vulvovaginitis merupakan faktor penyebab infeksi saluran kemih berulang. Gejala klinis saluran kemih biasanya terdapat pada $20-40 \%$ pasien. ${ }^{4}$ Pengobatan terpilih adalah krim estrogen topikal selama 1-2 minggu dengan efektivitas 90\%., ${ }^{2,6}$ Perlu dihindari pemberian krim lebih dari 3-4 minggu untuk mencegah absorbsi sistemik yang dapat menimbulkan pembesaran payudara. ${ }^{4}$ Pemisahan mekanis dianjurkan jika perlengketan tampaknya mudah dipisahkan dan tidak menyebabkan trauma. ${ }^{2,6}$

Hipertrofi labia minor jarang ditemukan. Kelainan ini dapat unilateral atau bilateral, simtomatik atau asimtomatik. Pasien sering mengeluh adanya iritasi atau rasa tidak nyaman ketika berjalan, berkendara, atau bersepeda. Pada hipertrofi labia yang simtomatik, dilakukan eksisi jaringan dan selama operasi dilakukan pemasangan kateter Fowley. Pada jenis yang asimtomatik tidak ada terapi khusus tetapi perlu penjelasan kepada pasien atau orangtua. ${ }^{1,2}$

\section{Pengobatan}

Leukorhoe fisiologis biasanya tidak memerlukan pengobatan karena akan sembuh sendiri, tetapi perlu memberikan pengertian kepada pasien atau orangtua bahwa keadaan ini bukan penyakit infeksi. Selain itu perlu perhatian terhadap higiene perineum, dan menggunakan pakaian yang tidak ketat dan tidak menghalangi penguapan. ${ }^{7}$ Dalam tata laksana vulvovaginitis non spesifik, perlu dijaga higiene perineum, tidak mengenakan pakaian yang ketat, menggunakan sabun yang lunak, dan memelihara vulva tetap kering. Pasien perlu diberitahu mengenai kebiasaan berkemih dan buang air besar yang baik, serta menjauhkan tinja dari daerah vulvovaginal. Vulvovaginitis berulang diterapi dengan antibiotik sistemik seperti amoksisilin atau sefalosporin. Krim estrogen topikal atau salep polisporin sangat membantu. ${ }^{1,2}$

Lesi yang akut, berair, vesikular, dan dermatitis pruritus, diterapi dengan kompres dengan larutan Burrowi, $\mathrm{NaCl}$ fisiologis, air bersih, atau larutan kompres lainnya selama 20-30 menit setiap 3 jam atau lebih. Pemberian bedak harus dihindari. Pemakaian sabun hendaknya dihindari karena dapat menyebabkan inflamasi. Infeksi kulit perlu diterapi dengan antibiotik sistemik. Biasanya fase akut akan mengalami perbaikan dalam 2-3 hari. Jika tidak terjadi perbaikan, perlu dilakukan reevaluasi, karena dapat terjadi reaksi berlebihan terhadap pengobatan, sabun, air hangat, wool, dan infeksi sekunder yang menimbulkan perburukan. Setelah fase akut mengalami perbaikan, dapat dilanjutkan dengan obat topikal seperti pemberian lotion antipriritus atau iodohidroksikuin dengan krim hidrokortison. Ointment atau pasta sebaiknya dihindari sebab dapat menyebabkan oklusi kulit. Untuk tindakan pencegahan, vulva dibersihkan dengan hati-hati 2 kali sehari dengan sabun nonmedicated dan non perfumed serta membersihkan smegma. Dengan adanya iritasi seperti pada dermatitis atopi, sabun dan air hangat hendaknya dihindari. Idealnya, vulva harus dibersihkan segera setelah buang air besar dengan membersihkan dari depan ke belakang. Mengenakan pakaian hendaknya memperhatikan sirkulasi udara dan hindari bahan yang menimbulkan panas dan mencegah penguapan. Vulva dijaga agar tetap bersih, sejuk, dan kering. ${ }^{4}$ Pada vulvovaginitis nonspesifik persisten atau berulang, jika vaginoskopi tidak menunjukkan kelainan, perlu dipertimbangkan pemberian estrogen topikal jika tidak ada masalah dengan pubertas prekoks. Setelah 2-3 minggu, keadaan ini akan menyebabkan penebalan dinding vagina, $\mathrm{pH}$ yang asam, dan dapat menyembuhkan vaginitis bakterialis non spesifik. ${ }^{4}$

Pada vulvovaginitis gonorhoe, antibiotik merupakan pengobatan yang efektif, dan diberikan seftriakson $25-50 \mathrm{mg} / \mathrm{kgbb}$ intramuskular atau intravena dosis tunggal. ${ }^{6}$ Vulvovaginitis oleh Gardnerella vaginalis diterapi dengan metronidazol, ampisilin atau sefalosporin oral, dan dapat juga dengan sulfonamid vaginal. ${ }^{4}$ Terapi terpilih untuk vulvovagintis oleh Shigela fleksneri dan Shigela sonnei adalah antibiotik sistemik. ${ }^{1,2}$ Untuk vulvovaginitis kandidiasis, 
anti jamur seperti imidazol, mikonazol, dan klotrimazol lebih efektif dibandingkan nistatin, sehingga obat ini telah menggantikan nistatin sebagai obat pilihan pada kandidiasis. Angka kesembuhan (cure rate) dengan pemberian 7 hari mencapai 86-94\%. Pemberian klotrimazol dosis tunggal atau 3 hari memberikan hasil yang memuaskan. ${ }^{7}$ Pengobatan topikal dapat dilakukan dengan pemberian krim imidazol atau klotrimazol, ${ }^{2,8}$ dan butokonazol (derivat imidazol). ${ }^{7}$ Vulvovaginitis trikomoniasis diterapi dengan metronidazol sebagai obat terpilih dengan dosis $10-30 \mathrm{mg} /$ kgbb per hari dibagi 3 dosis selama 5-8 hari. ${ }^{4,6,7}$ Jika terdapat benda asing, benda asing tersebut harus segera dikeluarkan. Benda lembut seperti kain atau kertas dapat dikeluarkan dengan melakukan irigasi vagina dengan cairan salin hangat. ${ }^{7}$ Meskipun kadang-kadang benda ini dapat dikeluarkan dengan aplikator khusus, vaginoskopi tetap diperlukan untuk melihat benda yang lain. ${ }^{4}$ Pemberian hidrokortison atau antihistamin dapat mengurangi proses peradangan. Kadang-kadang diperlukan antibiotik sistemik terutama jika terjadi infeksi sekunder. ${ }^{7}$

\section{Penutup}

Vulvovaginitis pada anak perlu mendapat perhatian karena hampir semua anak perempuan pernah menderita penyakit ini. Vulvovaginitis dapat disebabkan oleh bakteri, virus, jamur, protozoa, cacing, trauma, ataupun benda asing. Vulvovaginitis dapat juga merupakan bagian dari penyakit sistemik atau infeksi lain. Pengobatan vulvovaginitis tergantung pada penyebabnya, tetapi menjaga higiene perineum merupakan hal yang sangat penting.

\section{Daftar Pustaka}

1. Sanfilippo JS. Vulvovaginitis. Dalam, Behrman RE, Kliegman RM, Nelson WE, Vaughan III VC, penyunting, Nelson Textbook of Pediatrics, edisi ke-14, W.B. Saunders, Philadelphia, 1992, h. 1385-8.

2. Sanfilippo JS. Vulvovaginitis. Dalam: Behrman RE, Kliegman RM, Jenson HB, penyunting. Nelson Textbook of Pediatrics, edisi ke-17. Saunders, Philadelphia, 2004. h. 1828-32

3. Postlethwaite RJ, Dickson A. Common urologic problems. Dalam: Webb N, Postlethwaite RJ, penyunting. Clinical pediatric nephrology, edisi ke-3. Oxford Medical Publications, Oxford, 2003. h. 227-58.

4. Altchek A. Vulvovaginitis, vulvar skin disease, and pelvic inflammatory disease. Pediatr Clin N Am, 1981; 2:397-432.

5. Jaquiery A, Stylianopoulus A, Hogg G, Grover S. Vulvovaginitis: clinical features, aetiology, and microbiology of the genital tract. Archs Dis Child 1999; 81:64-7.

6. Brown MR, Cartwright PC, Snow BW. Common office problems in pediatric urology and gynecology. Pediatr Clins N Am. Pediatric Urology. 1997; 44:1091115.

7. Rosenfeld WD, Clark J. Vulvovaginitis and cervicitis. Pediatr Clin N Am, 1989; 3:489-511.

8. Savage JM, Postlethwaite RJ, Symptoms and signs of childhood renal tract disease. Dalam: Postlethwaite RJ, penyunting. Clinical pediatric nephrology, edisi ke-2. Butterworth Heinemann, Oxford, 1994. h. 75-88.

9. Demetriou E, Emans SJ, Masland RP. Disuria in adolescent girls: urinary tract infection or vaginitis. Pediatrics 1982; 70:299-301.

10. Pierce AM, Hart CA. Vulvovaginitis: causes and management. Archs Dis Child 1992; 67:509-12. 